\title{
Symbolism of Water in Classic and Modern Arabic Literature
}

\author{
Mohammad Hamad \\ Al-Qasemi Academic College of Education, Israel \\ Hamadm33@gmail.com
}

DOI: http://doi.org/ 10.36892/ijlls.v2i4.367

\begin{tabular}{l} 
Received: \\
05/07/2020 \\
\hline
\end{tabular}

Accepted:

08/12/2020

Keywords:

water; symbol;

literary meaning;

Arabic literature.

\section{Abstract}

Water in Arabic literature has literal and symbolic meanings. Water is one of the four elements in Greek mythology; life would be impossible without water and it is a synonym for life; life originated in water. Springs, wells, rain, seas, snow, and swamps are all associated with water. Each form of water may take on a different manifestation of the original from which it comes about. Arabic literature employs the element of water in poetry, the short story, and the novel. We find it in titles of poems: Unshudat al-matar (Hymn of the Rain) and Waj' al-ma' (The Pain of Water); and novels: Dhakirat al-ma' (The Memory of Water); Taht al-matar (Under the Rain); Matar huzayran (June Rain); AlBahr khalf al-sata'ir (The Seas Behind the Curtains); Rahil al-bahr (Departure of the Sea); and many others. This study aims to answer the following questions: How does the element of water manifest in Arabic literature? What are the semantics and symbolism of the different forms of water in the literary imaginary? The study refers to six different significations for water in classical and modern Arabic literature: water as synonymous with life, purity and the revelation of truth, separation and death, fertility and sex, land and homeland, and talent and creativity.

\section{INTRODUCTION}

Water is considered to be one of the basic elements of life, covering approximately $71 \%$ of Earth's surface. It is stated in religious texts that life was created from water, and that water is precedent to life, as it came in the Old Testament:" the earth was a formless void and darkness covered the face of the deep, while a wind from God swept over the face of the waters. (The book of Genesis, 2:1). And as it came in Quran "out of water, lives were created" (Qur'an, 21:30).

Humans have used waterways through time, they lived on the banks of rivers and near the shores of the seas, used it to communicate and used the power of water as foundations of agricultural and industrial life.

Humans also believed in Gods of the sea and the river, Poseidon was the God of the sea according to Greek mythology and Neptune according to Roman mythology and Hebo was the God of the Yellow River in Chinese beliefs, while in old Egyptian civilization, the origin of the Nile's water and its flow for the ancient Egyptians was the god Noun, the Lord of the eternal water, who was the cradle of all living beings including the gods themselves (Hassan, 2017). There were the lovers of the Nile Gods. Offerings for the river included animals and girls, as was the case in Egypt and China Bohai, n.d).

Religions came to give importance to water, as it was used in baptism in Christianity. While Islam used it in ablution before praying, as for Hindus, they believe that washing in the Ganges River cleanses them from sins. 
In the following lines we will explain the different significances of water throughout ages, within different fields by talking about the reflection of water in modern and classical Arabic texts.

\section{Water as a synonym for life}

In the pre-Islamic period of the jahiliyyah, water was usually associated with rain. A common practice was to pray for rain to fall on the grave of a dead person, and the expression saqa allahu qabra ${ }^{n}$ (May God pour water on a grave) was often used, as in al-Nabigha alDhubyani (1996):

Rain watered a grave between Busra and Jasim

with early rain, droplets and torrents. (p. 155)

And in Abd al-Samad ibn Salim al-Bahili:

Generosity and Abu Amr are enclosed by

a grave in Baghdad the rain seeks to water. (al-Dhubyani, 1996)

The Arabs believed in the power of certain graves to cause rainfall, especially those of kings, lords, and nobles, and they performed magic rituals over the bones of the dead and at their graves to invoke rain (al-Nahar, 2019). The invocation, May God water his grave, was a sign of the status of the person buried, who remained living in the grave, because the rainwater signaled life and its fall on the grave revived the person buried there. This interpretation is in agreement with the vision of Jesus in his conversation with the Samaritan women, when she understood "living water" to mean spring water, whereas Jesus meant eternal life (Marais, 2017). This same meaning is intended in the poem Momento Mori by Eminescu, where the river waters symbolize the endless flow of time, from a perspective that water is one of the four elements of Greek philosophy: water, air, fire, and earth (Golovanova, 2015).

In the Islamic period, there are clear references in the Qur'an to water as the origin of life. God makes all living things from water: "We made from water every living thing? Will they not then believe?" (Qur'an 21:30); and in the story of Moses, who is cast into the river when he was born to save him from Pharaoh: "Cast him in the ark, then cast him into the river, and then the river shall throw him up onto the shore; (there) an enemy of Mine and an enemy of his shall take him.' And I cast upon you a love from Me and that you might be reared under My eyes." (Qur'an 20:39). When Moses draws water for Shuaib's daughters, he rewards him with one of his daughters in marriage. The prophet Job bathes after his trials as a sign of a new life in a curative sense: " 'Stamp your foot. This is a cool bath and a drink." (Qur'an 38:42). In the Tiberius region in northern Palestine and the Jordan Valley there are many hot springs, used until today for curative purposes (Abu Jahjah, 1995).

Moving on to modern poetry, the Iraqi poet al-Bayyati (1989) has a poem entitled The Springs, where he talks of an Arab king, and sets the tribes in the context of rain: "A king over the mirages of the kingdom of the sand grouse/and tribes of rain at every season. / my gold is springs of life/and my wealth the angst of existing" (p. 15). It is clear here that the springs connote the origin of life and life itself, which is highly optimistic in terms of the Arab dream.

In The Deserted Well, Yusuf al-Khal (1979) likens Ibrahim to the well: "I knew Ibrahim, my dear neighbour, for a long time/He was a well whose water overflowed but people/passed by and did not drink from it, nor did they even drop a stone in it" (p. 203).

The overflow is linked with the well, and despite the symbolism of the name Ibrahim and its connection to the story of redemption and sacrifice, as reflected in his martyrdom in 
the poem, it still draws us to the religious intertextuality and the symbolism of the prophet Ibrahim residing in an uncultivated valley and the overflow of the well of Zamzam that coincides with this (Qur'an 14:37).

In the story Hayat by Muhammad Ali Saeed (1997), Ali Mahmoud escapes soldiers by going into a bathroom, where the pure and virtuous young woman Hayat is bathing. She hides him in the bathroom, despite the awkward situation, preferring national to personal duty. Hayat saves his life from the soldiers. The narrow confines of the bathroom with its abundance of water is akin to the womb, which provides the environment for formation and birth, and from which Hayat gives rebirth to the Palestinian refugee long pursued.

In contemporary sources from the Gulf, life takes on pragmatic meaning. Economic and working life might be made of water, for the peoples who have built their cities on the coast have benefitted from seas and rivers. In the novel Al-Sayf wal-zahra (The sword and the rose) by Ali Abul-Rish (2009), water (the sea) is a source of livelihood. People take pearls and fish to make a living.

The examples above show the meaning of life in the motif of water, in line with the religious tradition that all living things were created from water.

\section{Purity: revealing the truth and exposing the false}

Like ablutions in Islam or baptism in Christianity, here water represents the purification of the body, the revelation of the false clinging to it, and its preparation to meet the truth of faith. In the story of Solomon and Bilqis, water is used as a means to ascertain the truth of the rumours that Biqlis's legs were the legs of a donkey and that her mother was a jinn (al-Nisafi, 1998). "It was said to her, 'Enter the palace (hallway)'. And when she saw it, she supposed it to be a pool, and so she bared her legs. He said, 'It is a hallway paved (smooth) with crystal'. She said, 'My Lord, indeed I have wronged myself, and I submit with Solomon to God, the Lord of the Worlds"' (Qur'an 27:44).

One Thousand and One Nights contains many tales involving manifestations of water. Reciting a spell over water and then sprinkling it over an enchanted person to restore them to their original form occurs in the Tale of the Merchant and the Demon (Alf Layla wa-Layla, 1976), where this occurs in two tales, first when the wife turns the boy into a calf, and again when the unfaithful wife turns her husband into a dog. In both cases the enchanted are freed and the truth revealed.

In the story of Jubina (Haddad, 1991), she bathes in the pool and the behavior of the flocks changes, and the prince knows this after watching Jubina. Both Jubina and the slave Murjana bathe in hot water, and the truth about both is revealed after the slave takes on the personality of Jubina and forces her to take on her personality, partly by dying her skin. The hot water and bathing is the means to reveal the true situation.

In the poem Washing the Shame Away, Nazik al-Malaika (1971) uses washing metaphorically for the cleansing of the shame and disgrace caused by the girl according to the accusations of the townspeople. Although al-Malaika does not use the word water, washing involves water and its role in cleansing the body and wiping away sin.

\section{Water as a synonym for separation and death}

The story of the Flood is linked with the sense of rupture and death. The Flood was a punishment for the people of the prophet Noah (ibn Kathir, 2003). There is also the story of the drowning of Pharaoh and his people when the prophet Moses strikes the sea with his staff: "And when We divided for you the sea, and We delivered you, and drowned Pharaoh's folk, while you were beholding." (Qur'an 2:50). The story of Joseph is also relevant when his brothers cast him into the well (Qur'an 12:10). Although they do not wish to kill him, they 
punish him and deprive him of food and water, and cause him to be kept away from his father.

Returning to the story of Jubina, the blue bead falls into the well and Jubina is cut off from her mother, enabling the slave woman to assume Jubina's character, and Jubina to assume hers (Haddad, 1991). Here, the well symbolizes loss, separation, and distance.

On the linguistic level, there is the figure of the cup of death ( $\mathrm{ka}$ 's al-manun and $\mathrm{ka}$ 's al-manniyya), and the water basin ( $h u d ̣)$ where going down to death is likened to going down to drink. Abu Sakhr al-Hudhali says:

If the water trough of death with nought below it was in the place of the Pleiades you would be the first to drink (Dmitriev, 2008).

Antara likens the stabs of the lance to one drinking his blood, invoking his beloved Abla in this scene where there is a concentrated presence of the element of water:

I remembered you (Abla) as the lances drank deep

from me and the white sword dripped my blood. (Khafājīi, 1992)

He continues by likening the lances piecing his horse with the ropes to draw water from a well.

The troops called out "Antara!" while lances, long as

the ropes of a well, were thrust against the chest of my dark steed. (Khafājīi, 1992)

The lances drink from the source of blood just as the ropes drink from the source of water. This image of death is embodied in the dark colour of the horse and the darkness of well. Blackness was an objective correlative for the psychological state induced by the battle.

Al-Mutanabbi makes a metaphorical link between waves and death:

He built it high as spear clashed with spear

and the waves of death crashed and roared around it. (Māni', 1981)

In Mikhail Naimy's poem The Frozen River, there is a metaphorical meaning where the frozen river, the drying up of the waters and the cease of its murmuring paint an image of death.

O river! Have your waters run so dry that I no longer hear your murmuring?

Or have you grown old? Has your will grown weak? Have you ceased your flowing?

('Ali, 2005)

In the tale of Hassan the Merchant, the sultan enters the pool and into a time of fantasy, or what is called time travelling, in that he experiences life for several years, but when he comes out of the pool, he finds the astonished dervish and soldiers waiting for him. The king is amazed and asks them why they are still waiting for him, given that he has been gone some years. In reality he has only gone for a few moments. The pool is the entrance to the unknown, and coming out of it led the king to be punished by losing his throne and being accused of madness (Muhabbak, 1999).

Badr Shakir al-Sayyab's poem, The Song of the Rain, should not be taken as a hymn of joy as its title might suggest. The rain is the tears of the clouds and a focus of sadness:

The song of the rain ... 


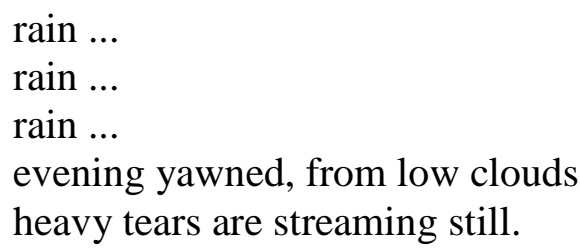

The mother in the grave remains:

in the hillside, sleeping her death for ever,

eating the earth around her, drinking the rain. (al-Sayyāb, 2015)

Rain is tears, and the dead drink, as if life and death were a cycle.

\section{The sexual allusions of water}

Due to its presence in pleasure, fertility, and fertilization, water has sexual connotations. Thirst for water may metaphorically means sex, as in the story Iftiras (Predation) by Muhammad Ali Saeed, when a wife slips away from her husband into the kitchen when she feels thirsty. A lion who wants to eat her comes out of the refrigerator, which is the water store (Saeed, 1997).

The sexual allusions are clear in Emily Nasrallah's story Layla wal-Dhi'b (Layla and the Wolf): thunder as the voice of desire; the liquid mixed in the cake; and the rain that cleanses the sin, all suggest a sexual encounter (Nasrallah, 1998).

Returning to the pre-Islamic period, in his Muallaqah, Imru al-Qays recalls the day he encountered the maidens who had gone down to bathe in the pool at Darat Juljul and whose clothing he steals. He makes it a condition that they appear naked before he slaughters his she-camel and feeds them (Imru al-Qays, 1964). The link between the pool and the erotic scene is clear.

The relationship between rain and earth is a fecund fertile one. In Greek myth, King Acrisios imprisons his daughter Danäe in a chamber under the ground. Through the cracks in the roof, Zeus comes to her in the form of golden rain, and she becomes pregnant ( Trzaskoma et al. 2004).

In Yahya Yakhlif's novel Nahr yastahamm fi al-buhayra (A river bathing in the lake) the sexual connotation of water is clearly present. Yakhlif tries to mythologize the fluid contours of Palestine in a way that gives an aura of sanctity: "Men said that the river was male and the lake female. At the fish breeding season, the lake would acquire a red tinge, and they said the lake was menstruating, and passing through its fertile stage, and they wove mythic tales around what was happening in its depths. The river would emerge washed and purified, potent and wrapped in a dark blue cast by the dense growth of trees on the banks (Yakhlif, 2018). It is easy to imagine the long narrow river as the male member, entering the lake, like the female sex, in a graphic image.

\section{Water as equivalent for homeland}

Al-Mutanabbi inadvertently drew the geographical bounds of the Arab nation in his famous lines:

Behold a rosy lion! when seeking out a lake to drink

His roar resounds as far as the Euphrates and the Nile. (al-Ma'arrī, 2008)

In this section, however, the researcher will focus on the well as a motif with positive connotations expressing the homeland and territorial belonging. Wells also have negative 
connotations, expressing darkness, secrets, ambiguity, and unknowable destiny in other contexts.

In his story Bir al-Safa (The Well of Safa), Muhammad Ali Taha (2004) relates what happens to a Palestinian refugee when he returns to his birthplace Mi'ar from Lebanon. He reaches the well of Safa: "He did not find the young girls in their shawls or the earthenware water jars. He did not hear a whinny, or a moo, or a bleat, or a bray. Dry thorns surrounded the well. He reached the well's opening and hungrily breathed in its air. "Allah, Allah," he said, "Awad, how often we quenched our thirst from this sweet water" (p. 112).

The well is a symbol for the homeland and the life of the Palestinians before the Nakba and the occupation.

In Attalla Jabr's story al-Bi'r (The Well), a stranger who speaks Arabic with a foreign accent enters a house and asks for its owner, who is the mother of the narrator. He goes into the courtyard and makes for the well, as if he knows where it is. As soon as he finds it, he sticks his head over the edge and starts inhaling the air and crying violently. He is recalling his childhood in the house, his memories. It becomes clear that he is Milad, the prodigal son, who embraces his mother and relates the depth of the Palestinian tragedy. The well here is a symbol for the homeland and lost childhood in that homeland (Jabr, 2007).

Perhaps this commingling of the homeland and lost childhood is best embodied in leading Palestinian writer Jabra Ibrahim Jabra's autobiography Al-Bi'r al-Awwal (The First Well). The first well is a symbol for the features of the Palestinian house, since every household digs a well to store rainwater. The first well is Jabra's childhood in his autobiography (Jabra, 2009).

In Palestinian memory, accumulated water is associated with the homeland. The River Jordan and the Lake of Tiberius are part of the homeland for Yahya Yakhlif in his novel Nahr yastahamm fi al-buhayra (A river bathing in the lake), where he looks at the River Jordan flowing out of the Lake of Tiberius with a historical eye as the site of Christian baptism.

\section{Talent and Creativity}

Water-related imagery is used to describe creativity and talent in writing (al-bahr, sea, or poetic meter; and al-madad, tide, or ink). The Umayyad poet Jarir was said to ladle from the sea, and his great rival al-Farazdaq was said to sculpt stone, in reference to their linguistic and poetic talents.

The liquid property of ink is directly linked with the sea in the Qur'an: "Say: 'If the sea were ink for the Words of my Lord, the sea would be spent before the Words of my Lord were spent even though We brought the like of it as replenishment." (Qur'an 18:109).

In the story Taht sath al-hibr (Under the Surface of Ink) by Suhail Kiwan (2005), the narrator - and implied author - speaks of ink as a synonym for literary talent and the strictures of self-censorship over the text (pp. 17-20).

The poet Hafiz Ibrahim (1987) has the Arabic language describe itself metaphorically:

I am the sea hiding the pearl

But have the pearl-divers sought my shells? (p. 254)

\section{CONCLUSION}

Across the eras and genres of Arabic literature, water is manifested in many forms whose meanings both vary and overlap. This study considered six meanings for water: life, separation and death, revelation of truth and elimination of falsehood, sex, the nation, and literary and linguistic talent. Apart from separation and death, all these meanings are positive. 
The Greek hero Achilles was granted protection when his mother dipped him in the waters of the River Styx, but his weak point was his heel that was not immersed, and he died during the Trojan war from an arrow to his heel. This story suggests a future research project into the meanings of water in world literature and the cultural differences therein.

\section{REFERENCES}

Abu al-Rish, A. (2009). Al-Sayf wal-zahra. Damascus/Cairo: Dar al-Kitab al-'Arabi.

Abu Jahjah, Kh. (1995). Al-Ma' bayn al-adab wal-hayat. Dar al-Fikr, Vol. 16, No. 82: 111139.

al-Bayyati, A. (1989). Bustan 'Aisha. Cairo: Dar al-Shuruq.

Alf lalya wa-layla. (1976). Egypt: Dar al-Ma'arif.

'Ali, 'A. (2005). Literary text in the modern era between modernity and tradition. Cairo: The New Book Press.

al-Khal, Y. (1979). Yusuf al-Khal al-a 'mal al-shi 'riyah al-kamila. Beirut: Dar al-'Awda, 2nd edn.

al-Ma'arrī, (2008). Al-Lāmi' al-'Azizī fì Sharh Dīwān al-Mutanabbì. Muhammad Mulawī (ed). Riyād: King Faisal Center for Research and Islamic Studies.

al-Malaika, N. (1971). Qararat al-mawja. Beirut: Dar al-‘Awda.

al-Nabigha al-Dhubyani. (1996). Diwan al-Nabigha al-Dhubyani. 3rd edn, Beirut: Dar alKutub al-'Ilimiya.

al-Nahar, T. (2019). Ritha' al-khulafa' wal-qada fi al- 'asr al-ummawi. Beirut: Dar al-Kutub al-'Ilimiya.

al-Nisfi. (1998). Madarik al-tanzil wa-haqa'iq al-ta'wil, 20 vols. Beirut: Dar al-Kalm alTayyib.

al-Sayyab, B. Sh. (2015). Unshudat al-matar. Egypt: Mu'asassat Hindawi lil-Ta'lim walThaqafa.

al-Shajari. (1970). Al-Hamasa al-Shajariya. Damascus: Manshurat Wazarat al-Thaqafa.

Bohai, X. (n.d). The similarities between Hapi and Hebo, 1-40. Suzhou: Suzhou Industrial Park.

Dmitriev, K. (2008). Das Poetische Werk des Abu șakhr al-Hudhali- Eine Literaturanthropologische Studie. Wiesbaden: Harrassowitz Verlang.

Golovanova, E. (2015). The Water Symbolism in the Poem "Memento Mori” by Eminescu. Journal of Danubian Studies and Research, Vol. 5, No. 2: 200-207.

Haddad, H. (1991). Hikayat al-khala Dalla. Ibillin: S. A. lil-Tiba'ah wal-Nashr.

Hassan, A.H. (2017, September 7). Egypt and controlling the Nile: From mythologies to real politics. Pambazuka News, Thursday, pp. 1-8. (https://www.pambazuka.org). 
ibn Kathir. (2003).Al-Bidaya wal-nihaya. Riyadh: Dar 'Alam al-Kitab.

Ibrahim, H. (1987). Diwan Hafiz Ibrahim. Cairo: General Egyptian Book Organization.

Imru al-Qays. (1964). Diwan Imru al-Qays. Egypt: Dar al-Ma‘arif.

Jabr, A. (2007, January, 27). Al-Bi'r. Al-Akhbar newspaper, pp. 6-95.

Jabra, J. (2009). The First Well. Beirut: al- 'Adāb Press.

Khafāī̄i, M. (1992). Dirāsāt fill- 'Adab al-Jāhilī w-lislāmī. Egypt: Dār al-Jīl.

Kiwan, S. (2005). Taht sath al-hibr. Ramallah: Dar al-Majid.

Māni‘, S. ( 1981). Sayfiyyāt al-Mutanabbī. Riyād: University of Riyād.

Marais, N. (2017). Rainmustfall - A Theological Reflection on Drought, Thirst, and the Water of Life. Acta Theologica, 37(2):69-85.

Muhabbak, A. (1999). Folklore Tales. Damascus: Arab United Writers.

Nasrallah, E. (1998). Al-Layali al-ghajariya. Beirut: Dar Nawfal.

Saeed, M. A. (1997). Ahmad wa-Murdakhai. Haifa: Manshurat Mawaqif/Mu'asassat alMawakib.

Taha, M. A. (2004). Bir al-Safa. Amman: Dar al-Shuruq lil-Nashr wal-Tawzi`.

The book of Genesis.

The holy Qur'an.

Trzaskoma, S.M; Smith, R. S \& Brunet, S. (Eds). (2004). Anthology of Classical Myth. Indianapolis/Cambridge: Hackett Publishing Company, Inc.

Yakhlif, Y. (2018). Nahr yastahamm fi al-buhayra. Ramallah: Dar al-Buhayra.

\section{$\underline{A U T H O R ' S B I O}$}

Dr. Mohammad Hamad is currently a lecturer of modern Arabic literature, and head of department of Arabic language and literature in al-Qasemi Academic college of education within Israel. He graduated from Haifa University, in 2007, and his thesis was about "Metafiction in the Arabic novel". He is supervisor for M.Ed. students in Arabic Language instruction in Oranim College. Dr. Hamad wrote several textbooks, in Arabic, for elementary, junior and secondary schools; also he participated in some International conferences, about Arabic literature and caricature. His main researches already focus on Palestinian literature and children literature. 